\title{
Rabbit Beta-migrating Very Low Density Lipoprotein Increases Endothelial Macromolecular Transport without Altering Electrical Resistance
}

\author{
Mahamad Navab, * Gregory P. Hough, Judith A. Berliner,‡ Joy A. Frank, $\$$ Alan M. Fogelman, \\ Margaret E. Haberland," and Peter A. Edwards ${ }^{\star} \|$ \\ ${ }^{*}$ Division of Cardiology, Department of Medicine; and $\ddagger$ Departments of Pathology, §Physiology, and $\|$ Biological Chemistry \\ School of Medicine, University of California at Los Angeles, California 90024
}

\begin{abstract}
Rabbit aortic endothelial cells (RAEC) were grown on micropore filters in a new device. This system allowed in situ measurement of transendothelial electrical resistance (TEER). The monolayers demonstrated a TEER of $14 \pm 1 \Omega \cdot \mathrm{cm}^{2}$ at confluence. No difference was seen in the transport of low density lipoproteins (LDL) across endothelial cell monolayers obtained from normal or Watanabe heritable hyperlipidemic rabbits, indicating that the LDL receptor was not involved in the LDL transport. TEER was inversely correlated with ${ }^{22} \mathrm{Na}$ transport $\left(r^{2}=0.93, P=<0.001\right)$ but not with ${ }^{125} \mathrm{I}-\mathrm{LDL}$ transport. The amount of LDL transported at $15^{\circ} \mathrm{C}$ or across glutaraldehyde-fixed monolayers was half that of the controls at $37^{\circ} \mathrm{C}$. Preincubation of the monolayers with rabbit beta-migrating very low density lipoproteins ( $\beta$-VLDL) increased cholesterol content by $65 \%$, and the transport of albumin and LDL doubled without a change in TEER. Removal of $\beta$-VLDL from the culture medium resulted in the return of cellular cholesterol content and LDL transport to control values.

We conclude that preincubation of RAEC with $\beta$-VLDL resulted in an increased permeability to LDL and albumin, and that $\beta$-VLDL may promote increased transendothelial transport of macromolecules in cholesterol-fed rabbits.
\end{abstract}

\section{Introduction}

While the rabbit has proven to be a useful model of atherosclerosis, relatively few studies (1-3) have employed cultured rabbit aortic endothelial cells (RAEC). ${ }^{1}$ This has been partly due to technical difficulties in culturing the cells and partly due to a lack of data comparing known characteristics of these cultured cells with those in vivo. The availability of the Watanabe heritable hyperlipidemic (WHHL) rabbit, a genetic model of familial hy-

Address reprint requests to Dr. Fogelman, Division of Cardiology, Department of Medicine, Room 47-123 CHS, University of California at Los Angeles, Los Angeles, CA 90024.

Received for publication 19 September 1985 and in revised form 10 April 1986

1. Abbreviations used in this paper: BHT, butylated hydroxytoluene; $\beta$ VLDL, beta-migrating very low density lipoprotein(s); Dil-Ac-LDL, 1,1'dioctadecyl-1-3,3,3',3'-tetramethyl-indo-carbocyanine perchlorate; DME, Dulbecco's modified Eagle's medium, ECGS, endothelial cell growth supplement; FBS, fetal bovine serum; FITC, fluorescein isothiocyanate LPDS, lipoprotein-deficient serum; RAEC, rabbit aortic endothelial cells TEER, transendothelial electrical resistance; WHHL, Watanabe heritable hyperlipidemic.

J. Clin. Invest.

(c) The American Society for Clinical Investigation, Inc.

0021-9738/86/08/0389/09 \$1.00

Volume 78, August 1986, 389-397 percholesterolemia (4), has added significantly to the value of the rabbit model in atherosclerosis research. We therefore developed methods for reproducibly culturing RAEC. We have found that these cultured cells have many of the characteristics of RAEC in vivo.

Cholesterol feeding in rabbits results in increased permeability of the vascular endothelium to macromolecules (5). Animals on a high cholesterol diet exhibit several changes in serum lipoprotein pattern, including the appearance of significant quantities of beta-migrating very low density lipoproteins $(\beta$ VLDL) (6). Incubation of endothelial cells with $\beta$-VLDL has been shown to cause a significant increase in cholesterol content that is mediated by an endothelial cell $\beta$-VLDL receptor (7). In order to study the possible mechanisms involved in the increased permeability of the vascular wall of cholesterol-fed rabbits, we developed a new system. Monolayers of RAEC were grown on micropore filters in a special device, forming a chamber on each side of the monolayer. A unit was developed to measure the transendothelial electrical resistance (TEER) in situ. Low density lipoprotein (LDL) from different sources was prepared and its movement across the monolayer examined after preincubation of the monolayers with different lipoproteins. We found that preincubation of RAEC monolayers with $\beta$-VLDL resulted in a significant increase in the transfer of LDL and albumin across the monolayer without a change in TEER.

\section{Methods}

Materials. Dulbecco's modified Eagle's medium (DME), pancreatin, trypsin, and other tissue culture materials were obtained from Gibco, Grand Island, NY. Collagenase type 1/No. C 0130, gelatin No. G 2500, dextran No. D 4133, butylated hydroxytoluene (BHT), heparin No. H 3125 , rabbit serum albumin, and dimethylsulfoxide were obtained from Sigma Chemical Co., St. Louis, MO. Human fibronectin and endothelial cell growth supplement (ECGS) were purchased from Collaborative Research Inc., Lexington, MA. Acetylated LDL labeled with 1,1'-dioctadecyl$1-3,3,3^{\prime}, 3^{\prime}$-tetramethyl-indo-carbocyanine perchlorate (Dil-Ac-LDL) was obtained from Biomedical Technologies, Inc., Cambridge, MA. Goat anti-human Factor VIII antigen labeled with fluorescein isothiocyanate (FITC) was purchased from Atlantic Antibodies, Scarborough, ME. Na ${ }^{125}$ I ( $15 \mathrm{mCi} / \mu \mathrm{g}$ of iodine) was obtained from Amersham Corp., Arlington Heights, IL. and ${ }^{22} \mathrm{Na}$ (>100 Ci/g sodium) as sodium chloride was obtained from New England Nuclear, Boston, MA.

$R A E C$. New Zealand white or WHHL rabbits weighing between 2 and $3 \mathrm{~kg}$ each were used to obtain RAEC. The rabbit was anesthetized using $0.5-1.0 \mathrm{ml}$ of pentobarbital solution $(50 \mathrm{mg} / \mathrm{ml})$. Most of the blood was removed from the abdominal aorta at the bifurcation. The thoracic portion of the aorta was dissected out, inverted, and ligated at both ends. The aorta was incubated in a $37^{\circ} \mathrm{C}$ solution of $0.1 \% \mathrm{wt} / \mathrm{vol}$ collagenase in DME containing $0.08 \% \mathrm{wt} / \mathrm{vol}$ pancreatin for three consecutive 10 min intervals in a $37^{\circ} \mathrm{C}$ incubator. After each incubation, cells were dislodged by stretching and relaxing the aorta in a 100 - $\mathrm{mm}$ diameter culture dish, and by pipetting a stream of the $37^{\circ} \mathrm{C}$ enzyme solution 
against the endothelium. A total of $5 \mathrm{ml}$ of the enzyme solution was used for each aorta. Using $5 \mathrm{ml}$ of DME containing 15\% fetal bovine serum (FBS), the isolated cells in the enzyme solution were transferred into a tube and centrifuged at $150 \mathrm{~g}$ for $7 \mathrm{~min}$ at room temperature. The cells from each 10-min incubation were resuspended in $1.0 \mathrm{ml}$ of the growth medium and seeded in one well $\left(2 \mathrm{~cm}^{2}\right)$ in a 24-well plate precoated with $0.1 \% \mathrm{wt} / \mathrm{vol}$ gelatin and fibronectin $\left(1 \mu \mathrm{g} / \mathrm{cm}^{2}\right)$. The growth medium used was DME supplemented with FBS (15\%), L-glutamine (2 $\mathrm{mM})$, sodium pyruvate $(1 \mathrm{mM})$, nystatin $(20 \mathrm{U} / \mathrm{ml})$, penicillin $(100 \mathrm{U} /$ $\mathrm{ml})$, and streptomycin $(100 \mu \mathrm{g} / \mathrm{ml})$. In addition, $5 \% \mathrm{wt} / \mathrm{vol}$ dextran was included in the growth medium for the first three passages. $24 \mathrm{~h}$ after the initial seeding, cells were rinsed with the growth medium to remove the red blood cells and other unattached cells. After an additional $2 \mathrm{~d}$, the medium was supplemented with ECGS $(20 \mu \mathrm{g} / \mathrm{ml})$ and heparin $(90$ $\mu \mathrm{g} / \mathrm{ml}$ ). Within a week, colonies of healthy endothelial cells formed in $30 \%$ of the wells. These cells had a slightly elongated appearance with cobblestone (8) areas. Cells that did not appear to be endothelial were scraped away with the fire-bent tip of a Pasteur pipette. The endothelial cells received fresh medium every $48 \mathrm{~h}$ and were allowed to cover the well. Subconfluent monolayers were passaged serially and split at a ratio of $1: 3$ using $0.01 \%$ trypsin in $2 \mathrm{mM}$ EDTA. The use of ECGS and heparin in subcultures with seed densities of $10^{4}$ cells $/ \mathrm{cm}^{2}$ or more was not essential. At passage 7, a portion of the cells was frozen in growth medium containing $10 \%$ dimethylsulfoxide and stored in liquid nitrogen. For transport studies, cells from passage 7 were grown on micropore filters (\#110413; Nucleopore Corp., Pleasanton, CA) pretreated with $0.1 \%$ gelatin and fibronectin $\left(1 \mu \mathrm{g} / \mathrm{cm}^{2}\right)$. The seeding density was $5 \times 10^{4}$ cells $/ \mathrm{cm}^{2}$.

Stains. Cultured RAEC were washed with DME, and Dil-Ac-LDL $(10 \mu \mathrm{g} / \mathrm{ml}$ in DME) was added to the cell monolayer. After $4 \mathrm{~h}$ of incubation at $37^{\circ} \mathrm{C}$, the medium containing Dil-Ac-LDL was removed. Cells were washed three times with DME and fixed with $3 \%$ formaldehyde in phosphate-buffered saline. The cells were visualized using standard rhodamine excitation-emission filters. For Factor VIII antigen staining, cells grown on glass coverslips were fixed for $15 \mathrm{~min}$ in $100 \%$ acetone. The fixed cells were then air dried and treated for $1 \mathrm{~h}$ with a 1:50 dilution of FITC-labeled goat IgG anti-human Factor VIII antigen. Goat antihuman FITC labeled-IgG served as a control. Endothelial cell monolayers on filters were stained with silver nitrate using the method described by Furie et al. (9).

Electron microscopy. Thin-section electron microscopy was performed as previously described (10).

Freeze-fracture. Endothelial cells grown on culture dishes were fixed with $2 \%$ glutaraldehyde in $0.1 \mathrm{M}$ cacodylate and cryoprotected $(25 \%$ glycerol in buffer) while still attached to the culture dish. The cell layer was gently lifted off the dish and folded onto a gold specimen hat (Balzer's, Hudson, NH). The hats and layered cells were frozen for freezefracture as previously described (10). The fracturing and shadowing were done in a Freeze-Etch Unit 301; Balzer's. Specimens were fractured at $-120^{\circ} \mathrm{C}$ at a vacuum between 2 and $4 \times 10^{-7}$ torr. Replication occurred immediately upon evaporating carbon-platinum onto stationary specimens from a standard electron beam gun mounted at a $45^{\circ}$ angle. The platinum replica was digested and cleaned as previously described (10). All electron microscopic observations were made on a $100 \mathrm{CX}$ microscope (JEOL USA, Cranford, NJ).

Transport system. We developed a new system (Fig. 1) for the study of lipoprotein transport across endothelial monolayers. In this system a 13-mm diameter polycarbonate filter impregnated with $0.1 \%$ gelatin (11) was placed and held tight between two silicone gaskets. This divided a U-shaped tube into two equal sized chambers in a unit (Fig. 1, $A$ and $B$ ) made from Lexan (General Electric Plastics, Inc., Mt. Vernon, IN). Each unit accommodated six filters forming six chambers on each side. The unit was then gas sterilized and, using sterile techniques, the filters were coated with fibronectin before seeding the cells.

Lipoproteins and albumin. LDL was isolated from the sera of fasting New Zealand white or WHHL rabbits or from fasting healthy human subjects by sequential ultracentrifugation at $d=1.019-1.063 \mathrm{~g} / \mathrm{ml}$ (12).

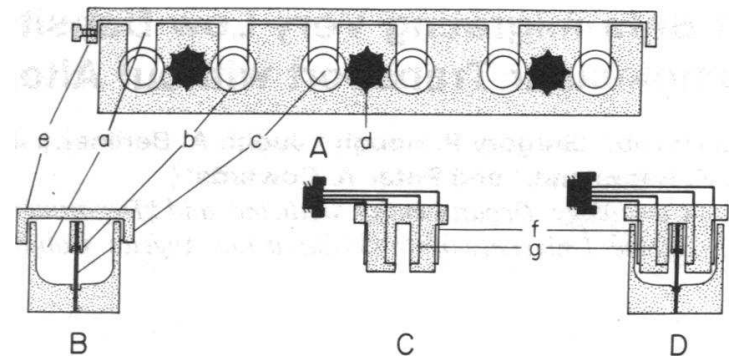

Figure 1. Schematic diagram of the device developed for transport experiments; $(A)$ side view; $(B)$ end view; $(C)$ electrodes for measuring the electrical resistance; and $(D)$ electrodes in place in the chamber. Each transport unit has 12 chambers $(a)$. Silicone gaskets $(b)$ hold micropore filters $(c)$ tightly in place after the brass knobs $(d)$ tighten the two half-units together. Cells are seeded on filters with the unit on its side. The lid (e) is then put in place. After 3-4 h in the incubator, the unit is turned upright and growth medium added to the chambers. For measuring the electrical resistance, the unit with source $(f)$ and detecting $(g)$ electrodes is inserted into the chambers, an alternating current is passed and potential difference across the filter measured. The distance between the source electrodes is $20 \mathrm{~mm}$ and that between the detecting electrodes is $3.0 \mathrm{~mm}$.

Iodination of LDL and albumin was performed by the method of Bilheimer et al. (13). $\beta$-VLDL from rabbits fed a $3 \%$ cholesterol diet for 8 10 wk (14) was kindly provided by Dr. Brian Van Lenten (Division of Cardiology, University of California at Los Angeles, CA). The concentration of each lipoprotein is given as the protein concentration.

$L D L$ or albumin transport. Postconfluent RAEC monolayers on filters were washed with DME containing $4.5 \mathrm{mg}$ protein/ $\mathrm{ml}$ of human or rabbit lipoprotein-deficient serum (LPDS-DME) $(d>1.21 \mathrm{~g} / \mathrm{ml})$. Subsequently we found that there was no difference in the results when the LPDS was obtained from either human or rabbit serum (data not shown). Therefore, the experiments were conducted with human LPDS. Human LDL, or rabbit LDL, or rabbit albumin at $100 \mu \mathrm{g} / \mathrm{ml}$ and specific activity of $60,000 \mathrm{cpm} / \mu \mathrm{g}$ ( ${ }^{125} \mathrm{I}$-protein) in LPDS-DME was added to the chambers on the apical side of the monolayer (the cell side of the filter). Chambers on the basal side (the side of filter without cells) had identical medium without added LDL or albumin. In most experiments, the units were placed on a shaker adjusted to 150 strokes/min, parallel to the plane of the filter in a $37^{\circ} \mathrm{C}$ cell culture incubator, with $5 \% \mathrm{CO}_{2}$ and $95 \%$ air. In experiments comparing $\mathrm{LDL}$ transport at $37^{\circ} \mathrm{C}$ and at $15^{\circ} \mathrm{C}$ the experimental conditions were modified as follows: $(a)$ the units containing the monolayers were placed in a temperature-controlled water bath on the shaker in the incubator, and $(b)$ after the desired temperature was reached and maintained, the transport experiment was initiated with the units being shaken at 150 strokes/min in a direction perpendicular to the plane of the monolayers. At desired time intervals, samples were removed from the basal side and trichloroacetic acid-precipitable counts were determined. In some experiments, samples from the basal side were pooled to give $1 \mathrm{mg} \mathrm{LDL}$ protein/ml medium and were applied to a column of Sepharose CL $2 B(60 \times 0.9 \mathrm{~cm})$ and were eluted with 0.15 $\mathrm{M} \mathrm{NaCl}, 10 \mathrm{mM}$ Na phosphate, pH 7.4, containing 0.01\% EDTA. The void volume was $36 \mathrm{ml}$ and $0.5-\mathrm{ml}$ fractions were collected at a rate of $20 \mathrm{ml} / \mathrm{h}$. In transport experiments, filters without cell monolayers served as controls. Whenever a sample was removed it was immediately replaced by an equal volume of prewarmed LPDS-DME.

Sodium transport. ${ }^{22} \mathrm{Na}$ of high specific activity ( $>100 \mathrm{Ci} / \mathrm{g}$ sodium) was diluted in LPDS-DME to give a specific activity of $1000 \mathrm{cpm} / \mu \mathrm{g}$. Transport of sodium across the RAEC monolayer was then examined in a manner identical to that used for LDL.

Electrical resistance. TEER was measured in situ using the device (Fig. $1 C$ ) developed for us by John Parker and Ivan Whitehorn of the University of California at Los Angeles Cardiovascular Research Laboratory, CA. Before and after each transport experiment, TEER values 
were determined. A $0.1-\mathrm{mA}$ alternating current was passed across the monolayer and, by employing Ohm's law, the observed potential difference was used to calculate the TEER.

Chemical fixation. Monolayers of RAEC grown on filters for $7 \mathrm{~d}$ in DME containing 15\% FBS were washed with modified Tyrode's solution containing $40 \mathrm{~g} /$ liter dextran (73,000 molecular weight) (15). After three 5 -min washes at $37^{\circ} \mathrm{C}$, the monolayers were fixed with $2.5 \%$ glutaraldehyde in $0.05 \mathrm{M}$ Na-cacodylate buffer, $\mathrm{pH} 7.4$, at $37^{\circ} \mathrm{C}$ for $30 \mathrm{~min}$. This solution also contained $40 \mathrm{~g} /$ liter dextran. The monolayers were then washed with the Tyrode's solution and used in the LDL transport experiments.

Incubation of RAEC with lipoproteins. On day 7 of seeding, the monolayers reached confluence and developed their maximum TEER. At this time, the monolayers were washed with LPDS-DME and were incubated in LPDS medium containing BHT $(20 \mu \mathrm{M})(16)$ and the desired levels of various lipoproteins.

Other assays. Angiotensin-converting enzyme was measured with the kit from Ventrex Laboratories Inc., Portland, ME, by following the recommended procedure. Thiobarbituric acid-reactive substances in the medium containing $\beta$-VLDL or LDL incubated with or without cells was determined as described by Morel et al. (16). Cell protein was determined by the method of Lowry et al. (17). The cellular free and esterified cholesterol content was measured as described by Fielding et al. (18). Student's $t$ test was used for statistical evaluations.

\section{Results}

Cells in culture. RAEC grown in culture showed a positive fluorescence after treatment with Dil-Ac-LDL (data not shown). In addition, staining of RAEC monolayers for Factor VIII-related antigen demonstrated a positive reaction (data not shown). The cells also demonstrated angiotensin-converting enzyme activity $\left(18 \mathrm{nmol} / \mathrm{h}\right.$ per $10^{6}$ cells). Electron microscopy indicated that the cultured RAEC have a structure similar to in vivo arterial endothelial cells (Fig. 2). In vivo, these cells are connected to each other by both tight and gap junctions (19). Both types of junctions were seen in micrographs of the freeze-fractured RAEC monolayer (Figs. 3 and 4). The tight junctions appeared more extensive and had the typical configuration of arterial endothelium reported by Simionescu et al. (19) where particles appear on the $\mathrm{E}$ face (membrane face closest to extracellular space) in contrast to other endothelial cells. When the membranes of the tight junctions were split, the $E$ face showed a continuous chain of grooves marked by rod-like particles which appeared fused into long chains (Fig. 4, $a$ and $b$ ). On the other hand, the P face (membrane face closest to protoplasm) contained complementary ridges that had fine furrows at their top. Most of the furrows

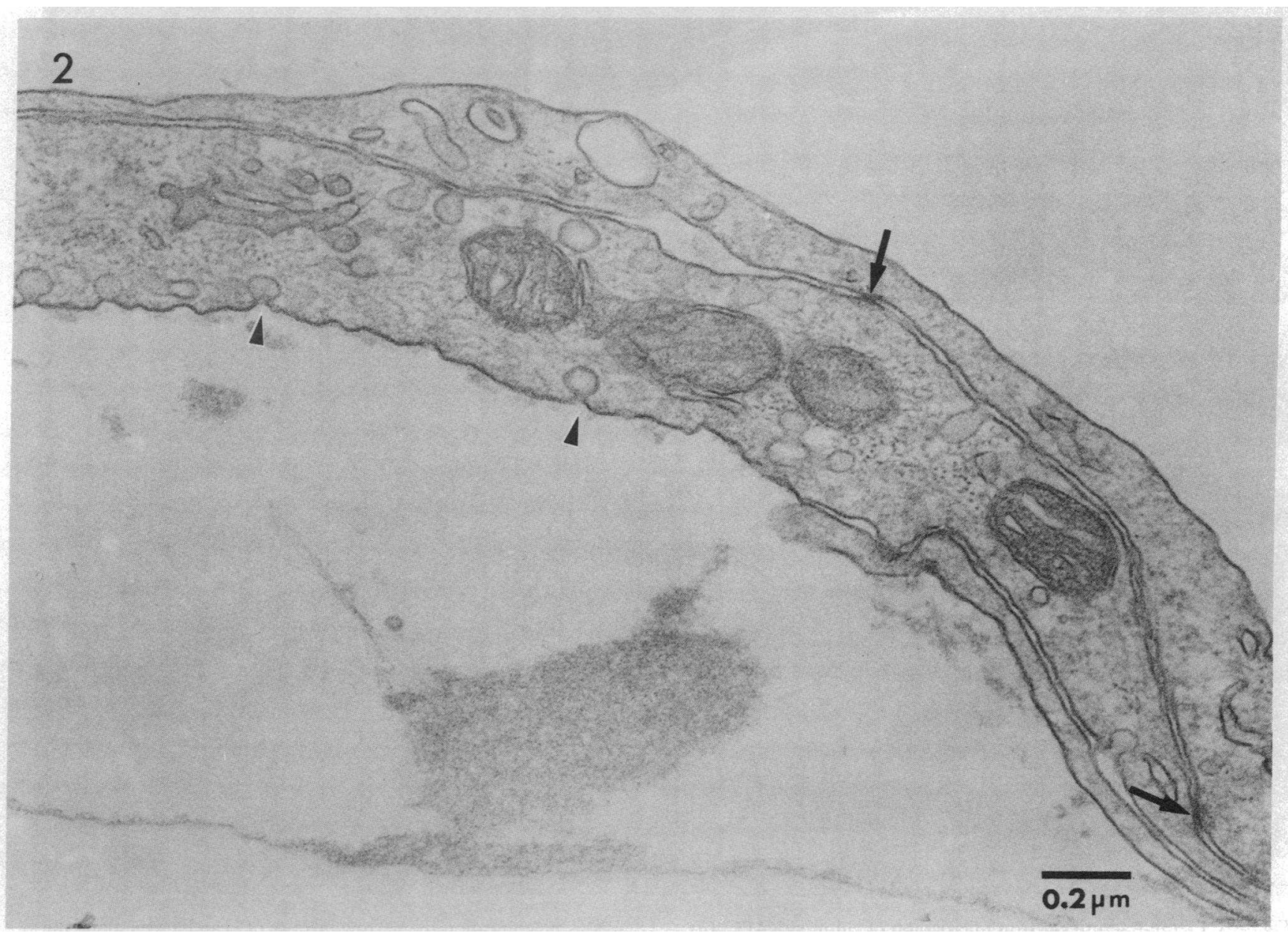

Figure 2. Thin-section electron micrograph showing a cross section of endothelial monolayer in culture. Where cells come together, large areas of overlapping cytoplasmic processes are present. Small areas of the plasmalemma of neighboring cells form what appear to be tight junctions (arrows). Cells contain numerous pinocytic vesicles (arrowheads) $(\times 61,991)$. 
were particle-free but occasionally some particles were seen (Fig. $3, a$ and $b$ ). The gap junctions were present in close proximity to the tight junctions (Figs. $3 b$ and $4 b$ ). The characteristic cluster of particles on the $P$ face and pits on the $E$ face were small in these cells but were clearly defined as part of a gap junction. The form and location of these junctions were typical of intact arterial endothelium.

The RAEC monolayers from both normal and WHHL rabbits demonstrated silver lines seen in intact aortic endothelium in situ (20) (data not shown).

TEER. The time course of the development of TEER is shown in Fig. 5. Up to $2 \mathrm{~d}$ after seeding the cells, TEER was basically nondetectable. Significant resistance was observed by day 5 , and peaked on day $7\left(14 \pm 1 \Omega \cdot \mathrm{cm}^{2}\right)$. During the second week the monolayers maintained in the medium containing $15 \%$ FBS showed a significant daily decline in TEER. The other group of monolayers that were transferred to LPDS-DME on day 7 continued to maintain a high TEER during the following $10 \mathrm{~d}$.

$L D L$ transport. The passage of LDL across the filters with and without RAEC is shown in Fig. 6. Presence of RAEC monolayers reduced the movement of LDL across the filters to about $2 \%$ of values obtained for plain filters. The surface area of the monolayer was $0.71 \mathrm{~cm}^{2}$, therefore the data in Fig. 6 represents $170 \pm 16$ vs. $9,295 \pm 785 \mathrm{ng} / \mathrm{h}$ per $\mathrm{cm}^{2}$ of LDL transported in the
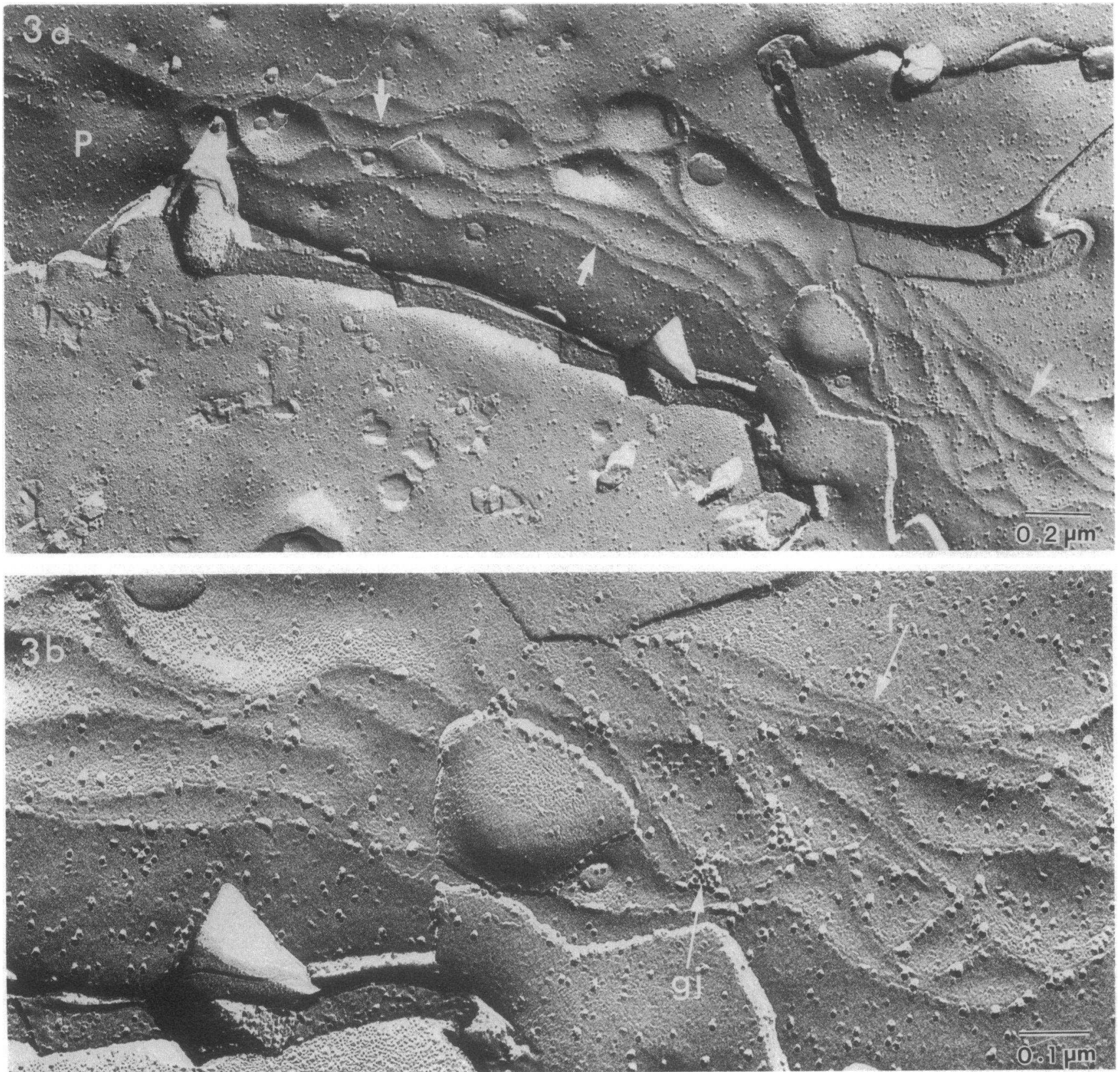

Figure 3. Freeze-fracture electron micrograph of cultured RAEC. (a) Low magnification showing extensive tight junction network (arrows). The junction seen here, on the $P$ face of the membrane, is a continuous network of ridges marked only by a few particles $(\times 52,704)$.

(b) Higher magnification of a portion of the same junction seen in $a$.
At this magnification the narrow furrows $(f)$ can be seen along the crest of the ridges forming the junction. Between the tight junction ridges are small clusters of particles from a gap junction $(\mathrm{gj})$ $(\times 110,808)$. 

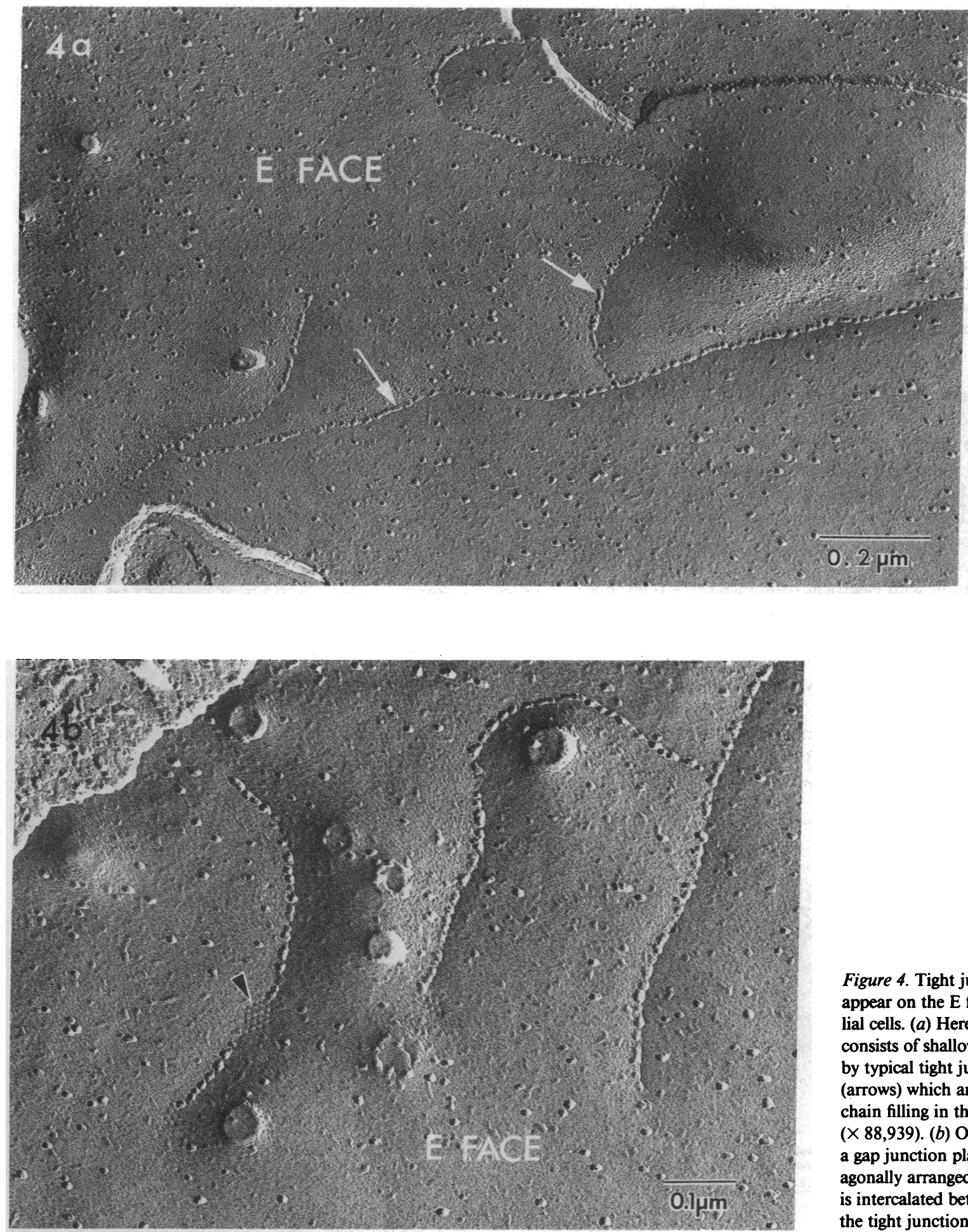

Figure 4. Tight junctions as they appear on the $E$ faces of endothelial cells. (a) Here the junction consists of shallow grooves marked by typical tight junctional particles (arrows) which are aligned in a chain filling in the groove $(\times 88,939)$. (b) On this cell (E face) a gap junction plaque, seen as hexagonally arranged pits, (arrowhead) is intercalated between strands of the tight junctions $(\times 118,972)$.

presence and absence of RAEC monolayers, respectively. $91 \pm 7 \%$ of the counts on the basal side were acid-precipitable $(n=98)$. Gel filtration on Sepharose CL 2B of the material that had crossed the monolayers indicated that $>90 \%$ of the radioactivity was eluted in particles that had the molecular size of LDL. No sig- nificant radioactivity was detected in later fractions (data not shown).

No difference was observed in the transport of human LDL as compared with rabbit LDL across the RAEC monolayers (data not shown). In addition, monolayers of cells from WHHL rabbits 


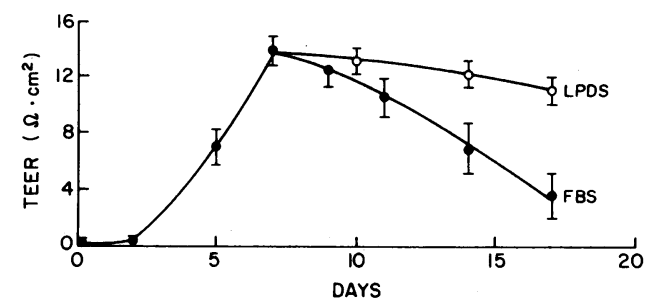

Figure 5. Development of electrical resistance of endothelial monolayers grown on filters. RAEC were seeded at $5 \times 10^{4}$ cells $/ \mathrm{cm}^{2}$ on pretreated filters and TEER was measured on days as indicated. The mean value obtained for filters without cells $\left(3.5 \pm 0.4 \Omega \cdot \mathrm{cm}^{2}\right)$ has been subtracted from values for monolayers. Results are mean \pm SD of values for six monolayers in DME containing FBS (๑) or LPDS (0).

that lack functional LDL receptor (4) transported the LDL to the same extent as did cells from normal rabbits (data not shown).

Increasing the concentration of LDL up to $100 \mu \mathrm{g} / \mathrm{ml}$ of medium resulted in a linear increase in the amount of LDL transported (Fig. 7). At higher concentrations of LDL, however, a reduced rate of increase was observed, indicating saturability of the transport mechanism.

Sodium movement across the RAEC monolayers showed an inverse correlation with electrical resistance $\left(r^{2}=0.93\right.$, Fig. $8 \mathrm{~A}$ ). Such a correlation was not observed for LDL (Fig. $8 \mathrm{~B}$ ).

Chemical fixation of the confluent monolayers resulted in a significant $(P<0.05)$ decrease in the amount of LDL that crossed the monolayer. The rate of LDL transport was halved (130.5 \pm 4.2 compared with $67.2 \pm 18.3 \mathrm{ng} \mathrm{LDL} / \mathrm{h}$ after fixation) while the electrical resistance of the monolayers changed $<12 \%(14.0 \pm 0.5$ compared with $12.4 \pm 0.4 \Omega \cdot \mathrm{cm}^{2}$ after fixation). Movement of LDL across chemically fixed filters without cells was not signif-

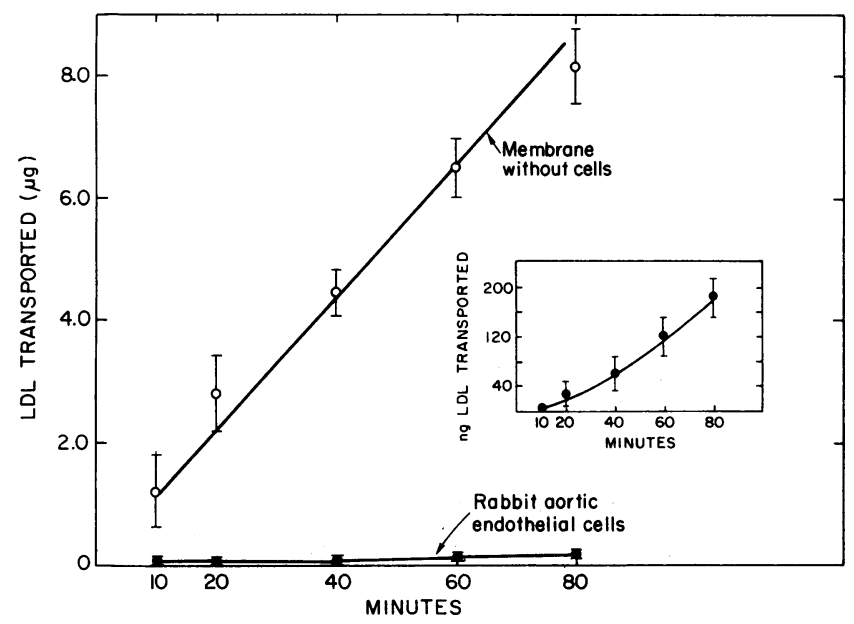

Figure 6. Movement of LDL across filters with (๑) or without (0) cells. ${ }^{125} \mathrm{I}-\mathrm{LDL}(100 \mu \mathrm{g} / \mathrm{ml}, 60,000 \mathrm{cpm} / \mu \mathrm{g})\left({ }^{125} \mathrm{I}\right.$-protein) in LPDS-DME was placed on the apical side of the monolayer. The transport was allowed to proceed on a shaker in a $37^{\circ} \mathrm{C}$ incubator. At the times shown on the abscissa, samples were removed from the opposite side and LDL transported determined. Values are mean \pm SD of measurements on six monolayers and represents LDL protein transported. The inset shows an enlarged portion of the graph displaying the values for filters with RAEC. Note that the ordinate in the inset represents nanograms transported whereas the ordinate of the large graph represents micrograms transported.

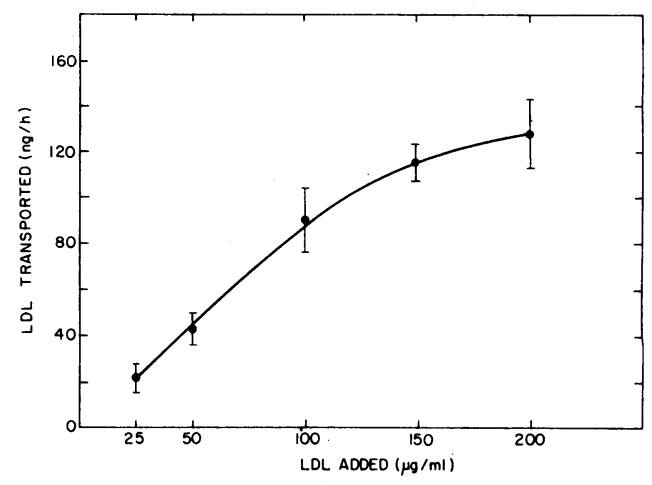

Figure 7. Effect of concentration on LDL transport across RAEC monolayer. ${ }^{125} \mathrm{I}-\mathrm{LDL}(30,000 \mathrm{cpm} / \mu \mathrm{g})$ was placed on the apical side of monolayers in the transport units. After $60 \mathrm{~min}$ of shaking at $37^{\circ} \mathrm{C}$, LDL transported was determined. Values are mean \pm SD for six monolayers and represent LDL protein transported.

icantly different from control filters $(4171 \pm 730$ vs. $4423 \pm 385$ ng $\mathrm{LDL} / \mathrm{h}$, respectively).

On reducing the temperature of the monolayers to $15^{\circ} \mathrm{C}$ there was also a significant decrease in the amount of LDL that crossed the monolayer $(134.7 \pm 8.5$ vs. $68.8 \pm 11.1 \mathrm{ng} \mathrm{LDL} / \mathrm{h}$ at $37^{\circ} \mathrm{C}$ and $15^{\circ} \mathrm{C}$, respectively). While the rate of LDL transport was halved, the electrical resistance of the monolayers was not significantly altered $\left(13.1 \pm 0.6\right.$ vs. $12.8 \pm 0.7 \Omega \cdot \mathrm{cm}^{2}$ at $37^{\circ} \mathrm{C}$ and $15^{\circ} \mathrm{C}$, respectively). Movement of $\mathrm{LDL}$ across filters without monolayers was not significantly different at $37^{\circ} \mathrm{C}$ or $15^{\circ} \mathrm{C}$ ( $6619 \pm 258$ vs. $6093 \pm 287 \mathrm{ng} \mathrm{LDL} / \mathrm{h}$ per $\mathrm{cm}^{2}$, respectively).

When confluent monolayers of RAEC on polycarbonate filters were exposed to $\beta$-VLDL for $5 \mathrm{~d}$, the cellular cholesterol
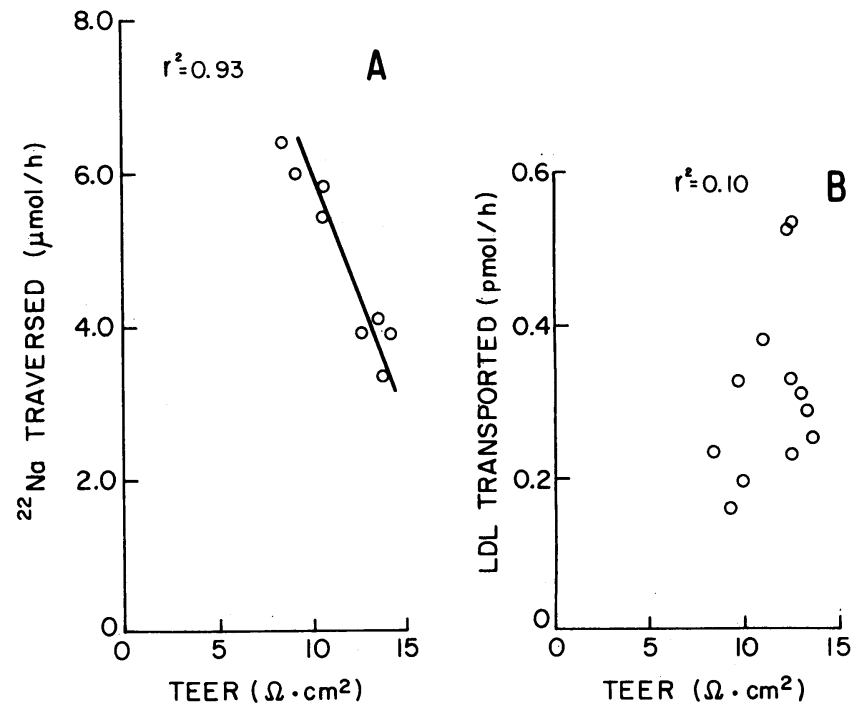

Figure 8. Correlation between TEER and LDL or sodium transport. TEER was measured on 72 monolayers that had been maintained in LPDS-DME for $7 \mathrm{~d}$. Less than 10\% of these monolayers had TEER of less than $10 \Omega \cdot \mathrm{cm}^{2}$ and none had a TEER greater than $15 \Omega \cdot \mathrm{cm}^{2}$. Monolayers with TEER between 8 and $15 \Omega \cdot \mathrm{cm}^{2}$ were randomly selected for study. LDL $(100 \mu \mathrm{g} / \mathrm{ml}, 60,000 \mathrm{cpm} / \mu \mathrm{g})$ or ${ }^{22} \mathrm{Na}\left(5.33 \times 10^{6}\right.$ $\mathrm{cpm} / \mathrm{ml} ; 1,000 \mathrm{cpm} / \mu \mathrm{g}$ ) was used in the transport system employing the RAEC monolayers with various TEER. Experiment was conducted as in Fig. 6. 
content increased by $65 \%$ (from $18 \pm 2.7$ to $30 \pm 3.1 \mu \mathrm{g} / \mathrm{mg}$ protein; $P<0.05$ ). Incubation with LDL, however, did not result in a significant change in cholesterol content of the RAEC monolayers (data not shown). After $5 \mathrm{~d}$ of exposure to $\beta$-VLDL, confluent monolayers of RAEC transported twice as much LDL as did the controls. Correcting the data from Fig. 9 for the surface area of the monolayers $\left(0.71 \mathrm{~cm}^{2}\right)$, monolayers exposed to $\beta$ VLDL transported $341 \pm 43 \mathrm{ng} \mathrm{LDL} / \mathrm{h}$ per $\mathrm{cm}^{2}$; monolayers not exposed to lipoprotein transported $165 \pm 18 \mathrm{ng} \mathrm{LDL} / \mathrm{h}$ per $\mathrm{cm}^{2}$; monolayers exposed to LDL at the same protein concentration as $\beta$-VLDL $(100 \mu \mathrm{g} / \mathrm{ml})$ transported $180 \pm 17 \mathrm{ng} \mathrm{LDL} / \mathrm{h}$ per $\mathrm{cm}^{2}$; and monolayers exposed to LDL at the same cholesterol concentration as $\beta$-VLDL $(670 \mu \mathrm{g} \mathrm{LDL}$ protein/ml) transported $198 \pm 22 \mathrm{ng} \mathrm{LDL} / \mathrm{h}$ per $\mathrm{cm}^{2}$. The difference at 30 and $60 \mathrm{~min}$ between the amount of LDL transported across the monolayers preincubated with $\beta$-VLDL compared with the other monolayers was significant at $P<0.001$ in each case (Fig. 9). The twofold increase in LDL transport induced by preincubation with $\beta$ VLDL (Fig. 9) was observed in each of five separate experiments. While there was a twofold increase in LDL transport induced by preincubation of the cells with $\beta$-VLDL (Fig. 9), there was no change in TEER $\left(12.8 \pm 1.4\right.$ and $13.8 \pm 0.8 \Omega \cdot \mathrm{cm}^{2}$ for controland $\beta$-VLDL-treated monolayers, respectively). The increased transport of LDL induced by preincubation with $\beta$-VLDL was not mediated by lipid peroxidation products. BHT was included in the medium as suggested by Morel et al. (16) and assay of our media demonstrated the absence of lipid peroxidation products (thiobarbituric acid-reactive substances).

The increase in LDL transport induced by preincubation with $\beta$-VLDL was reversible. After preincubating the cells with $\beta$-VLDL for $5 \mathrm{~d}$, LDL transport was increased by twofold (from $126 \pm 33 \mathrm{ng} / \mathrm{h}$ to $243 \pm 46 \mathrm{ng} / \mathrm{h}$, Fig. $10 \mathrm{~A}$ ) and cellular cholesterol content was increased by $65 \%(30 \pm 3.1 \mu \mathrm{g}$ cholesterol $/ \mathrm{mg}$ cell protein vs. $18 \pm 2.7 \mu \mathrm{g}$ cholesterol/mg cell protein for cells preincubated with $\beta$-VLDL or no lipoprotein, respectively). The in-

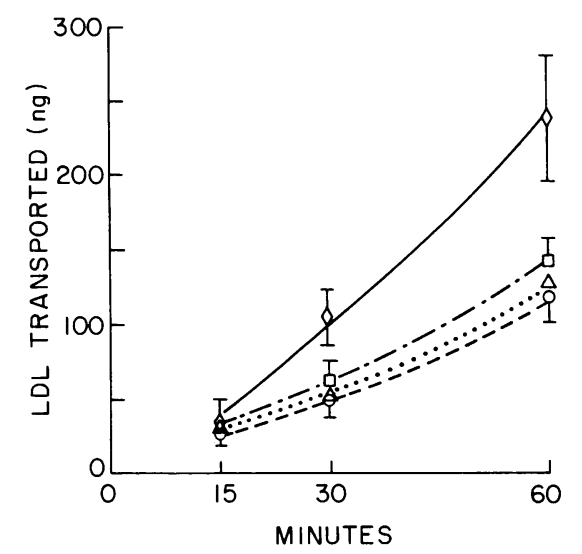

Figure 9. Effect of various lipoproteins on LDL transport. Confluent monolayers of RAEC were preincubated for $5 \mathrm{~d}$ with no lipoprotein (०, $n=30$ ), or $100 \mu \mathrm{g} / \mathrm{ml}$ of LDL $(\Delta, n=18)$, or $670 \mu \mathrm{g} / \mathrm{ml}$ of LDL $(\square, n=12)$, or $100 \mu \mathrm{g} / \mathrm{ml}$ of $\beta$-VLDL $(\diamond, n=30)$. The transport experiment was then conducted as in Fig. 6 . The values are the mean $\pm \mathrm{SD}$ of two to five experiments and represent LDL protein transported. In each experiment a minimum of six monolayers were used for each treatment. The total number of monolayers used for each treatment is shown in parenthesis next to the appropriate symbol in the legend.
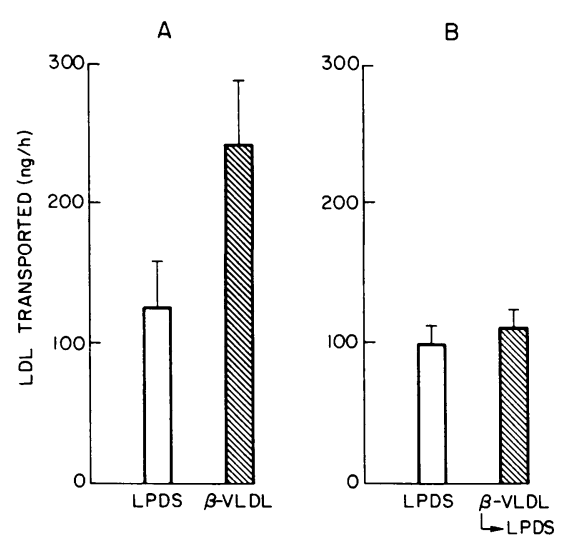

Figure 10. Effect of preincubation with $\beta$-VLDL and its subsequent removal from RAEC monolayers on LDL transport. $(A)$ Confluent RAEC monolayers were incubated with no lipoprotein (open bar) or with $100 \mu \mathrm{g} / \mathrm{ml}$ of $\beta$-VLDL (hatched bar) for $5 \mathrm{~d}$. LDL transport was then examined as in Fig. 6. $(B)$ monolayers used in the LDL transport experiment of $A$ were washed and incubated in LPDS-DME for $3 \mathrm{~d}$. At this time LDL transport was reexamined as in Fig. 6. Values are mean \pm SD from five monolayers and represent LDL protein transported.

creased cholesterol content of the cells exposed to $\beta$-VLDL was due to an increase in free cholesterol, as cholesteryl esters were not detected in either the control- or $\beta$-VLDL-treated monolayers. The medium was then changed to LPDS-DME for all chambers. After $3 \mathrm{~d}$ of incubation, the cholesterol content of cells previously exposed to $\beta$-VLDL was $20 \pm 2.3 \mu \mathrm{g}$ cholesterol/ $\mathrm{mg}$ cell protein and the cholesterol content of the cells that had not been exposed to $\beta$-VLDL was $18 \pm 2.1 \mu \mathrm{g}$ cholesterol $/ \mathrm{mg}$ cell protein. The decrease in cholesterol content of the cells previously exposed to $\beta$-VLDL was accompanied by a decrease in LDL transport to control values (Fig. $10 B$ ). There was no significant change in TEER under any of these conditions. Moreover, TEER was not significantly different before or after each transport experiment, indicating that the transport studies did not disrupt the monolayers.

The effect of preincubation of the monolayers with $\beta$-VLDL on albumin transport was also investigated. After $5 \mathrm{~d}$ of exposure to $\beta$-VLDL, albumin transport was approximately doubled (Fig. $11, P<0.01$ ) as was the case for LDL transport (Figs. 9 and 10).

\section{Discussion}

We have established a new in vitro system for studying the interaction of lipoproteins with monolayers of RAEC. All the subcultures of RAEC showed a strict contact-inhibited cobblestone morphology at confluence. The cell monolayers demonstrated angiotensin-converting enzyme activity, produced Factor VIII antigen, and bound Dil-Ac-LDL. Transmission electron microscopy and freeze-fracture showed that these RAEC in culture had many of the characteristics of intact RAEC in vivo, including the formation of gap and tight junctions and numerous pinocytic vesicles. The observation of cell borders stained with silver nitrate provided additional proof of monolayer formation on polycarbonate membranes. This pattern, also called flagstone (9), is strikingly similar to that reported for RAEC in vivo (20) or endothelial cells grown on human amnion (9). The transport system 


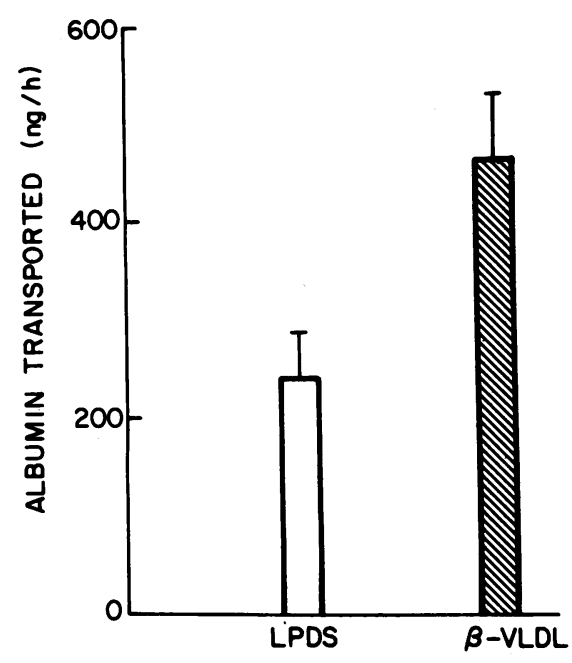

Figure 11. Effect of preincubation with $\beta$-VLDL on albumin transport. Confluent RAEC monolayers were treated as in Fig. $10 \mathrm{~A}$. The transport of rabbit serum albumin $(100 \mu \mathrm{g} / \mathrm{ml}, 60,000 \mathrm{cpm} / \mu \mathrm{g})$ was then examined as for LDL in Fig. 6 . Values are mean \pm SD from six monolayers.

we have developed has several advantages over the previous devices used for this purpose. Among the advantages are the following: $(a)$ it obviates the problems of hydrostatic pressure on monolayers grown in vertical chambers (ADAPS, Inc., Dedham, MA) (21), (b) it is excellent for studying transport in either direction, $(c)$ it permits repeated measurement of the TEER in situ, $(d)$ it allows easy and rapid loading and sampling without damage to the monolayer, $(e)$ it provides satisfactory mixing, $(f)$ it permits uniform coating of the filters and edge damage to the monolayers during manipulation is avoided, and $(g)$ it will accommodate several layers of various cell types (e.g., endothelial cells, smooth muscle cells etc.) and the addition of supplementary or auxilary units (e.g., for studying the effect of pressure).

The development of electrical resistance by rabbit endothelial cells grown on filters (Fig. 5) is almost identical to that of bovine aortic endothelial cells grown on filters that developed a maximum TEER of about $15 \Omega \cdot \mathrm{cm}^{2}$ at confluence (11). The decline in TEER of monolayers maintained in medium containing FBS (Fig. 5) for 2 wk may be due to continued cell growth in this serum or may be due to toxic substances in FBS. The decline in TEER in FBS after reaching a peak resistance at day 7 is similar to that reported for microvascular endothelial cells grown on amnion (9). The virtual maintenance of peak TEER when the cells were maintained in LPDS has not been previously reported and is a distinct advantage for a variety of studies.

In monolayers with high TEER $\left(>10 \Omega \cdot \mathrm{cm}^{2}\right)$, the transport of LDL (Fig. 6) was 1/50 that of filters without cells, demonstrating the efficiency of the RAEC monolayer as a permeability barrier. The similarity of the passage of human or rabbit LDL across the RAEC monolayer and similar transport of LDL by normal and WHHL cell monolayers indicated that the LDL receptor is not significantly involved in the transendothelial transport of LDL. This is in accordance with the findings of Wiklund et al. (22) on LDL penetration into rabbit aorta.

TEER is thought to be a sensitive measure of the passive permeation of small ions, such as sodium ion (23). The high inverse correlation $\left(r^{2}=0.93\right)$ observed between sodium transport and TEER (Fig. $8 \mathrm{~A}$ ) is consistent with this view. The passage of LDL, a much larger molecule, across the RAEC monolayer, however, did not correlate with TEER between 8.5 and 14.5 $\Omega \cdot \mathrm{cm}^{2}$ (Fig. $8 \mathrm{~B}$ ). This may mean that the number of channels available for the transport of a small molecule such as sodium is orders of magnitude greater than the very limited number of such channels that are available for the transport of a molecule the size of LDL (24-26). Thus, changes in LDL transport may not be accompanied by measurable changes in sodium transport and TEER. Additionally, we observed that approximately half of the LDL transported across the monolayer was dependent on energy-requiring processes. King and Johnson found that $65 \%$ of the transendothelial transport of insulin by the high-affinity insulin receptor was similarly dependent on temperature (27). LDL transport appears to be independent of the LDL receptor, as WHHL endothelial cells that genetically lack functional LDL receptors transported LDL as efficiently as normal endothelial cells. We interpret our data to indicate that, under these conditions, half of the LDL moved through channels between cells or through cells, while the other half was presumably transported by pinocytosis. The finding of saturability in the process is in agreement with a previous report (11), and may reflect both the small number of channels of a size sufficient for the transfer of LDL and a limited number of pinocytotic vesicles in these monolayers. Saturability may also reflect a limited capacity of the pinocytotic vesicles in these cells to enclose molecules that are as large as LDL (24-26).

Chobanian et al. (5) have reported that feeding rabbits a diet containing $1.5 \%$ cholesterol for 16 wk or more resulted in a marked increase in arterial permeability to albumin. This increase occurred to a degree that was disproportionately greater than the extent of atherosclerotic involvement of the intimal surface (5). It is well known that along with the hypercholestrolemia in animals fed a high cholesterol diet, cholesteryl esterrich $\beta$-VLDL appear in significant quantities in the plasma (6). Our results indicated that preincubation of confluent RAEC monolayers with $\beta$-VLDL significantly increased the passage of LDL and albumin across the monolayer (Figs. 9-11). This increase in transport required a minimum of $5 \mathrm{~d}$ of exposure to $\beta$-VLDL. Coincident with this increased permeability was the elevation of the cholesterol content of the cells, which is in agreement with a previous report (7). Preincubation of the monolayers with LDL, however, did not result in a significant increase in the cell cholesterol content or permeability of the monolayers to LDL (Fig. 9). The electrical resistance of the monolayers preincubated with or without $\beta$-VLDL was essentially the same, indicating that TEER and presumably $\mathrm{Na}^{+}$ transport were not affected by exposure of the cells to $\beta$-VLDL.

Attempts were made to investigate the possible mechanism(s) involved in the increased permeability to macromolecules in the monolayers that were preincubated with $\beta$-VLDL. The effect of chemical fixation or lowered temperature on permeability was therefore examined on these monolayers and their controls, which had been preincubated in LPDS-DME alone. Although these monolayers were very stable during the standard conditions used for the transport experiments, they showed a significant drop in the electrical resistance (20-30\%) upon lowering of the temperature to $15^{\circ} \mathrm{C}$ or during the fixation process. The drop in the resistance was more pronounced in the control monolayers that had been preincubated in LPDS-DME without the added $\beta$-VLDL (data not shown). Neither lowering the temperatures to $15^{\circ} \mathrm{C}$ nor chemical fixation altered the TEER of monolayers that had not been incubated in LPDS-DME. We suspect that 
the 5-d incubation in LPDS-DME paradoxically made the monolayers more stable under normal conditions (Fig. 5), but less stable under marked changes in temperature and after washing in a protein-free medium, as is required for chemical fixation. Therefore, we were unable to determine if the increased macromolecular transport induced by preincubation with $\beta$-VLDL was due to an increase in transport via an energy dependent process (e.g., pinocytosis), or an energy independent process (e.g., transport between cells), or an increase in both pathways. However, whatever the mechanism, it was clearly reversible, as removal of $\beta$-VLDL from the incubation medium led to a decrease in cellular cholesterol content and a return of transport to control values without a change in TEER (Fig. 10).

Hennig et al. (28) used monolayers of porcine arterial endothelial cells grown on filters for studies on albumin transport. They showed that high concentrations of fatty acids resulted in an increased transendothelial transport of albumin. Subsequently, Hennig et al. (29) have demonstrated an increased permeability to LDL using the same system. The effect on albumin transport was reversible $8 \mathrm{~h}$ after removal of the fatty acid. Exposure of the porcine endothelial cells to high concentrations of fatty acid also resulted in a large intracellular triglyceride accumulation and appearance of cytoplasmic inclusions (28). The authors suggested that changes in cell membrane characteristics resulted from altered lipid composition and were related to the increased transfer of albumin. In the present study, $\beta$-VLDLinduced changes in cellular cholesterol content was accompanied by a doubling in LDL and albumin transport without any change in TEER. Based on these studies, we hypothesize that the increase in the transport of macromolecules into the arterial wall of cholesterol-fed rabbits (5) may be induced in part by the interaction of $\beta$-VLDL with the arterial endothelium. The mechanism for the increased transport is as yet unknown and may involve perturbation of the physical properties of the endothelial cell membrane.

\section{Acknowledgments}

We thank Faranak Elahi, Kenneth Ho, Gregory Young, and Giuliano Mottino for their excellent technical assistance. We also thank Susan Murphy and Julie Ogasawara for the preparation of the manuscript.

This work was supported in part by United States Public Health Service grants HL 30568, IT32 HL 07412, and RR 865; grant 649 P5 from the American Heart Association, Greater Los Angeles Affiliate; the Laubisch Fund; and the M. K. Grey Fund.

\section{References}

1. Buonassisi, V., and J. C. Venter. 1976. Hormone and neurotransmitter receptors in an established vascular endothelial cell line. Proc. Natl. Acad. Sci. USA. 73:1612-1616.

2. Buonassisi, V., and P. Colburn. 1980. Hormone and surface receptors in vascular endothelium. $A d v$. Microcirc. 9:76-94.

3. Loskutoff, D. J., and T. S. Edgington. 1977. Synthesis of a fibrinolytic activator and inhibitor by endothelial cells. Proc. Natl. Acad. Sci. USA. 74:3903-3907.

4. Goldstein, J. L., T. Kita, and M. S. Brown. 1983. Defective lipoprotein receptors and atherosclerosis. N. Engl. J. Med. 309:288-296.

5. Chobanian, A. V., J. O. Menzoian, J. Shipman, K. Heath, and C. C. Haudenschild. 1983. Effects of endothelial denudation and cholesterol feeding on in vivo transport of albumin, glucose and water across rabbit carotid artery. Circ. Res. 53:805-814.

6. Mahley, R. W. 1978. Alterations in plasma lipoproteins induced by cholesterol feeding in animals including man. In Disturbances in Lipid and Lipoprotein Metabolism. J. M. Dietschy, A. M. Gotto, Jr., and J. A. Ontok, editors. American Physiological Society, Bethesda, MD. 181-197.

7. Baker, D. P., B. J. Van Lenten, A. M. Fogelman, P. A. Edwards, C. Kean, and J. A. Berliner. 1984. LDL, scavenger, and $\beta$-VLDL receptors on aortic endothelial cells. Arteriosclerosis. 4:248-255.

8. Schwartz, S. M. 1978. Selection and characteristics of bovine aortic endothelial cells. In Vitro (Rockville). 14:966-980.

9. Furie, M. B., E. B. Cramer, B. L. Naprstek, and S. C. Silverstein. 1984. Cultured endothelial cell monolayers that restrict transendothelial passage of macromolecules and electrical current. J. Cell Biol. 98:10331041.

10. Frank, J. S., T. L. Rich, S. Beydler, and M. Kreman. 1982. Calcium depletion in rabbit myocardium. Circ. Res. 51:117-130.

11. Territo, M., J. A. Berliner, and A. M. Fogelman. 1984. Effect of monocyte migration on low density lipoprotein transport across aortic endothelial cell monolayers. J. Clin. Invest. 74:2279-2284.

12. Fogelman, A. M., M. E. Haberland, J. Seager, M. Hokom, and P. A. Edwards. 1981. Factors regulating the activities of the low density lipoprotein receptor and the scavenger receptor on human monocytemacrophages. J. Lipid Res. 22:1131-1141.

13. Bilheimer, D. W., S. Eisenberg, and R. I. Levy. 1972. The metabolism of very low density lipoprotein. Biochim. Biophys. Acta. 260: 212-221.

14. Van Lenten, B. J., A. M. Fogelman, M. M. Hokom, L. Benson, M. E. Haberland, and P. A. Edwards. 1983. Regulation of the uptake and degradation of $\beta$-very low density lipoprotein in human monocytemacrophages. J. Biol. Chem. 258:5151-5157.

15. Haraldsson, B., and B. K. Johansson. 1985. Changes in transcapillary exchange induced by perfusion fixation with glutaraldehyde, followed by measurements of capillary filtration coefficient, diffusion capacity and albumin clearance. Acta. Physiol. Scand. 124:99-106.

16. Morel, D. W., P. E. DiCorleto, and G. M. Chisolm. 1984. Endothelial and smooth muscle cells alter low density lipoprotein in vitro by free radical oxidation. Arteriosclerosis. 4:357-364.

17. Lowry, O. H., N. J. Rosebrough, A. L. Farr, and R. J. Randall. 1951. Protein measurement with the Folin phenol reagent. J. Biol. Chem. 193:265-275.

18. Fielding, P. E., C. J. Fielding, R. J. Havel, J. P. Kane, and P. Tun. 1983. Cholesterol net transport, esterification, and transfer in human hyperlipidemic plasma. J. Clin. Invest. 71:449-460.

19. Simionescu, M., N. Simionescu, and G. E. Palade. 1976. Segmental differentiations of cell junctions in the vascular endothelium. $J$. Cell Biol. 68:705-723.

20. Poole, J. C. F., A. G. Sanders, and H. W. Florey. 1958. The regeneration of aortic endothelium. J. Pathol. Bacteriol. 75:133-143.

21. Goetzl, E. J., and K. F. Austen. 1972. A neutrophil-immobilizing factor derived from human leukocytes. J. Exp. Med. 136:1564-1580.

22. Wiklund, O., T. E. Carew, and D. Steinberg. 1984. Role of the low density lipoprotein receptor in penetration of low density lipoprotein into rabbit aortic wall. Arteriosclerosis. 5:135-141.

23. Crone, C., and O. Christensen. 1981. Electrical resistance of a capillary endothelium. J. Gen. Physiol. 77:349-371.

24. Curry, F. R. 1985. Mechanics and thermodynamics of transcapillary exchange. In Handbook of Physiology, Cardiovascular System IV. E. M. Renkin, and C. C. Michel, editors. American Physiological Society, Bethesda, MD. 309-374.

25. Simionescu, N., M. Simionescu, and G. E. Palade. 1976. Recent studies on vascular endothelium. Ann. NY Acad. Sci. 275:64-75.

26. Renkin, E. M., and F. R. Curry. 1982. Endothelial permeability: pathways and modulations. Ann. NY Acad. Sci. 401:248-259.

27. King, G. L., and S. M. Johnson. 1985. Receptor-mediated transport of insulin across endothelial cells. Science (Wash. DC). 227:15831586.

28. Hennig, B., D. M. Shasby, A. B. Fulton, and A. A. Spector. 1984. Exposure to free fatty acid increases the transfer of albumin across cultured endothelial monolayers. Arteriosclerosis. 4:489-497.

29. Hennig, B., D. M. Shasby, and A. A. Spector. 1984. Fatty acid exposure increases low density lipoprotein (LDL) transfer across cultured porcine pulmonary artery endothelium. Circulation. 70:186. (Abstr.) 